\title{
Leishmania amazonensis DNA in wild females of Lutzomyia cruzi (Diptera: Psychodidae) in the state of Mato Grosso do Sul, Brazil
}

\author{
Everton Falcão de Oliveira ${ }^{1 /}{ }^{+}$, Aline Etelvina Casaril ${ }^{2}$, Nathália Lopes Fontoura Mateus $^{2}$, \\ Paula Guerra Murat², Wagner Souza Fernandes², Elisa Teruya Oshiro², \\ Alessandra Gutierrez de Oliveira ${ }^{2}$, Eunice Aparecida Bianchi Galati, ${ }^{1,3}$

\footnotetext{
'Universidade de São Paulo, Faculdade de Saúde Pública, Programa de Pós-Graduação em Saúde Pública, São Paulo, SP, Brasil ${ }^{2}$ Universidade Federal de Mato Grosso do Sul, Centro de Ciências Biológicas e da Saúde, Campo Grande, MS, Brasil ${ }^{3}$ Universidade de São Paulo, Faculdade de Saúde Pública, Departamento de Epidemiologia, São Paulo, SP, Brasil
}

Studies on natural infection by Leishmania spp of sandflies collected in endemic and nonendemic areas can provide important information on the distribution and intensity of the transmission of these parasites. This study sought to investigate the natural infection by Leishmania in wild female sandflies. The specimens were caught in the city of Corumbá, state of Mato Grosso do Sul (Brazil) between October 2012-March 2014, and dissected to investigate flagellates and/or submitted to molecular analysis to detect Leishmania DNA. A total of 1,164 females $(77.56 \%$ of which were Lutzomyia cruzi) representing 11 species were investigated using molecular analysis; 126 specimens of Lu. cruzi were dissected and also submitted to molecular analysis. The infection rate based on the presence of Leishmania DNA considering all the sandfly species analysed was $0.69 \%$; only Leishmania (Leishmania) amazonensis was identified in $\mathrm{Lu}$. cruzi by the molecular analysis. The dissections were negative for flagellates. This is the first record of the presence of $\mathrm{L}$. (L.) amazonensis DNA in Lu. cruzi, and the first record of this parasite in this area. These findings point to the need for further investigation into the possible role of this sandfly as vector of this parasite.

Key words: natural infection - Lutzomyia cruzi - Leishmania amazonensis - molecular biology - polymerase chain reaction - dissection

The urbanisation of the human population and the transformation of the eminently rural cycle of leishmaniasis into a concomitantly urban and periurban phenomenon with the adaptation of some species of sandflies to urban environments have contributed to an increase in the incidence of the disease in Brazil in recent decades (Gontijo \& Melo 2004, Lainson \& Rangel 2005, Tauil 2006). According to the Information System on Notifiable Diseases (SINAN), 3,245 cases of visceral leishmaniasis (VL) and 3,188 cases of cutaneous leishmaniasis (CL) in humans were confirmed in the state of Mato Grosso do Sul (MS) between January 1999-December 2014 (dtr2004.saude.gov.br/sinanweb). In the city of Corumbá (MS), one of the oldest urban VL foci registered in Brazil, 104 human cases of VL and 21 of CL were confirmed between 2001-2013 (dtr2004.saude.gov.br/ sinanweb). However, there are no studies on genotyping of Leishmania species in this city, where Lutzomyia cruzi (Mangabeira, 1938) has been suspected as a vector of Leishmania (Leishmania) infantum [senior syn. of Leishmania (Leishmania) infantum chagasi (Cunha \&

doi: 10.1590/0074-02760150317

Financial support: FAPESP (2011/23414-0), FUNDECT/DECIT-MS/ CNPq/SES 04/2013 - PPSUS-MS - 23/200.537/2013

+Corresponding author: efalcao.oliveira@usp.br

Received 23 August 2015

Accepted 20 October 2015
Chagas, 1937)]. This suspicion was based on the absence of Lutzomyia longipalpis (Lutz \& Neiva, 1912), the main vector of this parasite in the Americas, together with ecological and epidemiological evidence (Galati et al. 1997), the observation of flagellates in dissected females and their identification as $L$. (L.) infantum by monoclonal antibodies (Santos et al. 1998), and the detection of the kDNA of this parasite followed by hybridisation (Pita-Pereira et al. 2008). Additionally, the vectorial competence of $L u$. cruzi for $L$. (L.) infantum and Leishmania (Leishmania) amazonensis Lainson \& Shaw, 1972 was demonstrated experimentally when this sandfly bite and transmitted these parasites to hamsters (Oliveira 2015). Thus, the participation of this sandfly in the transmission of Leishmania spp should be more investigated.

Studies investigating the natural infection of vector insects are useful to detect the intensity of the transmission of Leishmania Ross, 1903 and to understand the ecoepidemiology of leishmaniasis. Such studies are essential to local health authorities in their attempts to establish prevention measures and evaluate the effectiveness of programs aimed at controlling the transmission of leishmaniasis (Michalsky et al. 2002, Martín-Sánchez et al. 2006).

The high level of the sensitivity and specificity of molecular methods regardless of the number, stages of the life cycle and location of the parasites in the sandfly's gut (Perez et al. 1994, Pita-Pereira et al. 2005) are important for a better understanding of the epidemiology of leishmaniasis and the vector capacity of different species (Aransay et al. 2000, Perruolo et al. 2006). The polymerase chain reaction (PCR), widely employed in the analysis of entomological samples from different geographic regions (Feliciangeli et 
TABLE I

General characteristics of sampling sites in the city of Corumbá, state of Mato Grosso do Sul, Brazil, April 2012-March 2014

\begin{tabular}{|c|c|c|}
\hline $\begin{array}{l}\text { Residence } \\
\text { (neighbourhood) }\end{array}$ & Geographical location & $\begin{array}{l}\text { Domesticated animals } \\
\text { (n) }\end{array}$ \\
\hline Centro & $\begin{array}{l}\text { Central region of city; sampling } \\
\text { site closest to Paraguay River (approximately } 500 \mathrm{~m} \text { ) }\end{array}$ & $\begin{array}{c}\text { Dogs (2) } \\
\text { Chicken (1) }\end{array}$ \\
\hline Cristo Redentor & $\begin{array}{l}\text { Southeastern } \\
\text { periphery of the city }\end{array}$ & $\operatorname{Dog}(1)$ \\
\hline Maria Leite & $\begin{array}{l}\text { Northeastern } \\
\text { periphery of the city }\end{array}$ & $\begin{array}{c}\text { Dogs (2) } \\
\text { Chickens (15 }) \\
\text { Geese (5) } \\
\text { Ducks (3) }\end{array}$ \\
\hline Nova Corumbá & $\begin{array}{l}\text { Southern } \\
\text { periphery of the city }\end{array}$ & $\begin{array}{c}\text { Dogs (5) } \\
\text { Chickens (4) } \\
\text { Cats (3) }\end{array}$ \\
\hline Popular Nova & $\begin{array}{l}\text { Southeastern } \\
\text { periphery of the city }\end{array}$ & $\operatorname{Dog}(1)$ \\
\hline
\end{tabular}

$a$ : the number of chickens at this residence varied throughout the study, but was always greater than 15 .

al. 1994, da Silva \& Grunewald 1999, Aransay et al. 2000, Paiva et al. 2007), offers considerable sensitivity and specificity in the detection and identification of Leishmania species (Schönian et al. 2003).

The aim of the present study was to investigate the natural infection by Leishmania in wild female sandflies caught in Corumbá through dissection to investigate flagellates and/or detection of the Leishmania DNA.

\section{MATERIALS AND METHODS}

Study area - The specimens used in the present investigation were caught between October 2012-March 2014 in the urban perimeter of Corumbá (1900'33”S $57^{\circ} 39^{\prime} 12$ ' W; $118 \mathrm{~m}$ above sea level), which is located in the northeastern portion of MS (Central-West Brazil). The municipality has an area of $64,962.8 \mathrm{~km}^{2}$, which represents $18.19 \%$ of the total area of the state, and is located $415 \mathrm{~km}$ from the state capital (Campo Grande) in the Pantanal wetland region on the border with Bolivia.

Five collection sites (convenience sampling) were determined in neighbourhoods with records of human cases of VL in the year prior to the beginning of the study: four residential areas in the peripheral region and one in the commercial district of the city. Table I displays a brief description of the characteristics of each collection site.

Collections and acquisition of sandflies for molecular analysis - Automatic light traps were installed weekly in the peridomicile area of the five residences selected. For the identification of females, the genitalia were dissected on slides containing a drop of saline solution, whereas males were clarified and mounted on slides in balsam. The identification of both sexes was performed as described by Galati (2014). Engorged females and those whose entire bodies were clarified for the identification of the species were not included in the study.
In the first six months of analysis (October 2012-March 2013), females were grouped in pools of up to 10 insects of the same species, location and collection date, and placed individually in $1.5 \mathrm{~mL}$ microtubes with isopropyl alcohol and stored at $-20^{\circ} \mathrm{C}$ for subsequent PCR. The remaining specimens were placed individually in $1.5 \mathrm{~mL}$ microtubes.

Collections and acquisition of sandflies for dissection - A sample of females was dissected to investigate the presence of flagellates in accordance with the method described by Johnson et al. (1963). The specimens were caught with an aspirator in a chicken coop (the same collection site in the neighbourhood of Maria Leite used for the light trap collection) between 07:00 pm-09:00 pm on three different days (1 day in September 2013, 1 in November 2013, and the last in December 2013). After exposing the gut and spermathecae of the females for the investigation of flagellates and species identification, respectively, the contents on the slide (gut, thorax, and head) were transferred to $1.5 \mathrm{~mL} \mathrm{mi-}$ crotubes with isopropyl alcohol and stored at $-20^{\circ} \mathrm{C}$ for subsequent PCR. The specimens negative in the direct exam for flagellates were grouped in pools of up to ten.

$P C R$ and restriction fragment length polymorphism analyses - For DNA extraction, the specimens were ground with the aid of a plastic pestle in $1.5 \mathrm{~mL}$ tubes with $300 \mu \mathrm{L}$ of $5 \%$ Chelex $^{\circledR}$ resin solution (Bio-Rad, USA). The solution was mixed in a vortex for $15 \mathrm{~s}$, centrifuged at 13,000 rpm for $60 \mathrm{~s}$ and placed in a water bath at $80^{\circ} \mathrm{C}$ for $30 \mathrm{~min}$. The vortex and centrifugation procedures were repeated and the supernatant was removed and transferred to a different sterile Eppendorf tube. The extraction product was stored at $-20^{\circ} \mathrm{C}$.

PCR was performed targeting a region of the internal transcribed spacer (ITS) of the Leishmania ribosomal 
gene (ITS1) with approximately $300 \mathrm{bp}$. Five microlitre of the sample, $12.5 \mu \mathrm{L}$ of $\mathrm{GoTaq}^{\circledR}$ Green Master Mix (Promega, USA), $5.5 \mu \mathrm{L}$ of water, and $1 \mu \mathrm{L}$ of each oligonucleotide [LITSR (5'-CTGGATCATTTTCCGATG-3') and L5.8S (5'-TGATACCACTTATCGCACTT-3')] were added for a final reaction volume of $25 \mu \mathrm{L}$ (El Tai et al. 2000). The following manipulations were the amplification conditions in the thermal cycler (BIOER, China): $95^{\circ} \mathrm{C}$ for $3 \mathrm{~min}$ followed by 35 cycles of $95^{\circ} \mathrm{C}$ for $30 \mathrm{~s}$, $53^{\circ} \mathrm{C}$ for $30 \mathrm{~s}$, and $72^{\circ} \mathrm{C}$ for $1 \mathrm{~min}$, with post-extension at $72^{\circ} \mathrm{C}$ for $5 \mathrm{~min}$. The negative controls were a reaction without DNA containing water and DNA from nonfed $\mathrm{F}_{1}$ females. The positive controls were DNA from $L$. (L.) infantum (MHOM/BR/1972/BH46) and L. (L.) amazonensis (IFLA/BR/1967/PH8) extracted from cultures.

The PCR products were viewed using electrophoresis with $1.5 \%$ agarose gel in $100 \mathrm{~mL}$ of Tris-borate-ethylenediamine tetraacetic acid (TBE) buffer stained with GelRed $^{\mathrm{TM}}$ (Biotium, USA). The electrophoretic run was performed at $100 \mathrm{~V}$ for $100 \mathrm{~min}$ in concentrated TBE buffer. Viewing of the bands was performed using ultraviolet light with a $300-\mathrm{nm}$ filter.

The products from positive samples were submitted to HaeIII restriction enzyme digestion (isolated from Haemophilus aegyptius), which cleaves fragments in segments that have the $5^{\prime} \ldots \mathrm{GG}^{\mathbf{\nabla}} \mathrm{CC} \ldots . . .3^{\prime}$ or $3^{\prime} \ldots .$. CC $\mathbf{A G}$....5' sequence to identify the species of Leishmania (Schönian et al. 2003). One microlitre of 10x buffer, one unit of HaeIII enzyme and $1 \mathrm{mg}$ of DNA from the PCR were used and the volume was completed with $10 \mathrm{~mL}$ of ultrapure water. The sample was incubated in a water bath at $37^{\circ} \mathrm{C}$ overnight. The material was then submitted to electrophoresis in $2 \%$ polyacrylamide gel with TBE buffer for $3 \mathrm{~h}$.
Ethics - This study received the approval of the Animal Experimentation Ethical Committee of the Federal University of Mato Grosso do Sul (Brazil) under process 491/2013. The research group has a permanent license for the collection of zoological material issued by the Brazilian Institute of Environment and Renewable Natural Resources (SISBio 25952-1).

The field studies were carried out on private lands and the owners gave permission to conduct the collections and acquisition of sandflies in their peridomicile areas. Further, the field studies did not involve endangered or protected species.

\section{RESULTS}

During the weekly collections with light traps between October 2012-March 2014, 9,759 specimens (8,278 males and 1,481 females) were collected, belonging to 13 species: Brumptomyia brumpti (2), Evandromyia cortelezzii (4ㅇ), Evandromyia aldafalcaoae (3今̄, 5우), Evandromyia corumbaensis (41○े, 115우), Evandromyia sallesi $(6 \hat{\jmath}, 169)$, Evandromyia walkeri (4), Lu. cruzi (8,061 §े, 1,147우), Lutzomyia forattinii (125ㅅ, 159우), Micropygomyia peresi $(33 \hat{\partial}, 10$ ㅇ), Martinsmyia oliveirai $(8 \hat{\gamma}, 12+)$, Psathyromyia bigeniculata $(1 \hat{\jmath}, 2$ + $)$, Sciopemyia sordellii (4ㅇ), and Nyssomyia whitmani (1ㅇ). Among the total number of females collected, 1,038 were investigated for natural infection by Leishmania using only PCR. Another 126 females collected with an aspirator were dissected for the study of flagellates and subsequently analysed by the same method. Thus, 1,164 females were analysed by PCR (Table II).

Only eight of the 1,164 females $(0.69 \%)$ investigated exhibited a DNA band characteristic of Leishmania $(300$ bp). All naturally infected females were $L u$. cruzi, caught

TABLE II

Distribution of the sandfly females investigated for natural infection by Leishmania according to species and type of analysis

\begin{tabular}{|c|c|c|c|}
\hline \multirow[b]{2}{*}{ Species } & \multirow[b]{2}{*}{$\mathrm{n}(\%)$} & \multicolumn{2}{|c|}{ Analysis method } \\
\hline & & $\begin{array}{l}\text { Individual } \\
\text { (n) }\end{array}$ & $\begin{array}{c}\text { Pool } \\
\text { (number of pools) }\end{array}$ \\
\hline Brumptomyia brumpti & $1(0.09)$ & 1 & $0(0)$ \\
\hline Evandromyia aldafalcaoae & $3(0.26)$ & 3 & $0(0)$ \\
\hline Evandromyia cortelezzii & $3(0.26)$ & 3 & $0(0)$ \\
\hline Evandromyia corumbaensis & $95(8.16)$ & 91 & $4(2)$ \\
\hline Evandromyia sallesi & $11(0.95)$ & 11 & $0(0)$ \\
\hline Evandromyia walkeri & $1(0.09)$ & 1 & $0(0)$ \\
\hline Lutzomyia cruzi & $903^{a}(77.58)$ & 569 & $334(57)$ \\
\hline Lutzomyia forattinii & $133(11.43)$ & 133 & $0(0)$ \\
\hline Micropygomyia peresi & $1(0.09)$ & 1 & $0(0)$ \\
\hline Martinsmyia oliveirai & $10(0.86)$ & 10 & $0(0)$ \\
\hline Sciopemyia sordellii & $3(0.26)$ & 3 & $0(0)$ \\
\hline Total & $1,164(100)$ & 826 & $338(59)$ \\
\hline
\end{tabular}

$a$ : one hundred twenty-six of $903 \mathrm{Lu}$. cruzi females were dissected for flagellate study. 


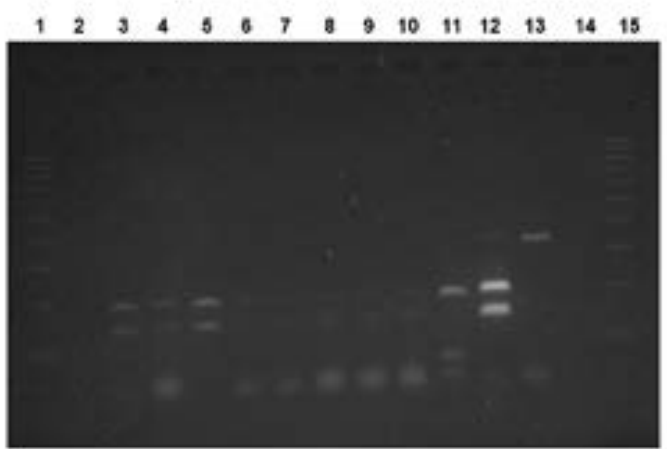

Digestion of amplified products from internal transcribed spacer 1 region of Leishmania with HaeIII restriction enzyme. Lane 1: ladder marker with 100 bp; 2: negative control (reaction without DNA containing water); 3-10: sample of wild sandflies naturally infected by Leishmania (Leishmania) amazonensis; 11: positive control by Leishmania (Leishmania) infantum (MHOM/BR/1972/BH46); 12: positive control L. (L.) amazonensis (IFLA/BR/1967/PH8); 13: sample not digested by HaeIII; 14: negative control (DNA from nonfed $\mathrm{F}_{1}$ females); 15: ladder marker of $100 \mathrm{bp}$.

on the same night in a single trap installed in the Maria Leite neighbourhood in June 2013. On this occasion, 272 sandflies were captured, 248 of them being males and 22 females, all of $\mathrm{Lu}$. cruzi, and one male each of $\mathrm{Lu}$. forattinii and of Mt. oliveirai. Thus, the natural infection rate of $L u$. cruzi was $0.89 \%$ (8/903) based on the presence of Leishmania DNA. The parasite identified in all the amplified products was L. (L.) amazonensis (200 bp and $140 \mathrm{bp)} \mathrm{(Figure).}$ Regarding the 126 females dissected for the study of flagellates, all were negative with both methods employed for the investigation of natural infection by Leishmania.

\section{DISCUSSION}

This study identified the natural infection of a sandfly species by a Leishmania species not yet reported during a regular survey of collections. Periodic surveys for the detection of natural infection by Leishmania are important for the understanding of the components of the parasite transmission chain. The detection of naturally infected sandfly species that have not previously been suspected as vectors of any Leishmania species demonstrates the need for studies to investigate their vectorial competence and the identification of permissive vectors (Kamhawi 2006, Paiva et al. 2007).

In the present study, the overall infection rate was $0.69 \%$ and the rate for $\mathrm{Lu}$. cruzi alone was $0.89 \%$. No flagellate forms were found in the dissected specimens and PCR was negative for all the pools analysed in this group. The females dissected were caught in a chicken coop close to the trap to which the positive females were attracted. In the chicken coop the females were collected with an aspirator while resting on the walls and birds. On the other hand, the light trap having light as its attraction may attract females which have had blood meals on various animals, including mammals which serve as reservoirs of Leishmania.
Although Lu. cruzi and Lu. longipalpis females are morphologically indistinguishable constituting a complex of species (Young \& Duncan 1994, Galati 2014), and despite the fact that Santos et al. (2003) reported the collection of three Lu. longipalpis males in Corumbá, the finding of only $L u$. cruzi males in the present investigation, as well as in previous studies (Galati et al. 1985, 1997, Santos et al. 1998, Pita-Pereira et al. 2008, Almeida et al. 2010, Casaril et al. 2014, Oliveira 2015), led us to identify all the females of this complex captured as $\mathrm{Lu}$. cruzi.

Different methods with different degrees of sensitivity and specificity have been employed for the detection of natural infection in blood-feeding insects, such as dissection for the direct study of flagellates, inoculation in experimental animal models and isolation of the parasite in a culture medium with dissected insects (Deane 1956, Lainson et al. 1985, Sherlock 1996). Although more expensive in comparison with other methods, PCR is a practical tool with high degrees of sensitivity and specificity and allows the grouping of individuals in pools (Schönian et al. 2003, Paiva et al. 2006, Savani et al. 2009). However, pooling may lead to the underestimation of the natural infection rate, as it is not possible to identify how many individuals were actually infected. In such cases, the calculation of the minimum infection rate (Paiva et al. 2006, 2010) and the estimation of the prevalence of infection using an algorithm (Katholi et al. 1995, Martín-Sánchez et al. 2006) have been employed. In order to estimate more accurately the possible natural infection rate, it was decided to analyse the specimens caught in light traps during regular collections from April 2013 individually.

This is the first report of the natural infection of $L u$. cruzi by $L$. (L.) amazonensis and of the presence of this parasite in Corumbá. Although Lu. cruzi has been studied little, the others reports of the finding of Leishmania DNA in wild females relate to $L$. (L.) infantum. Santos et al. (1998) found a $0.39 \%$ infection rate based on the dissection of 3,575 specimens of Lu. cruzi. Another 1,013 sandflies of seven different species were dissected and no flagellate forms were found. Based on these findings, the authors implicated $L u$. cruzi as a vector of $L$. (L.) infantum in Corumbá (Santos et al. 1998). In the same municipality, Pita-Pereira et al. (2008) found a 1.5\% minimum infection rate in $L u$. cruzi by $L$. (L.) infantum using the minicircle region of kDNA as the target of multiplex PCR with hybridisation. The minicircle region of kDNA has a high degree of sensitivity and is capable of detecting minimal quantities of Leishmania DNA (Smyth et al. 1992, Freitas-Lidani 2014). However, the minicircle region of kDNA only permits the identification of the genus of the parasite (Schönian et al. 2003).

For Lu. longipalpis, which is a confirmed vector of $L$. (L.) infantum, the first record of wild females naturally infected by $L$. (L.) amazonensis occurred in the city of Antônio João, located in the southeastern portion of MS, on the border with Paraguay (Paiva et al. 2006). Subsequently, other authors also found Lu. longipalpis naturally infected by the same parasite in the city of Bonito (Savani et al. 2009). These two locations, Antônio João and Bonito, are respectively endemic for canine VL and CL. 
The fact that the eight $L u$. cruzi females were caught on a single night with a single CDC trap installed in a peridomicile area demonstrates that the parasite seems not to be dispersed throughout the urban area. Additionally, in this case, a common source is strongly suggested for natural infection because only nonengorged females were analysed. The observation of a rodent of the genus Dasyprocta, considered a secondary host of $L$. (L.) amazonensis (Lainson et al. 1994, Ashford 2000, Lainson \& Shaw 2005), in the peridomicile area where the infected specimens were collected may explain these results. Factors that can contribute to the presence of this rodent in the area include the location of the dwelling on the outskirts of the town, a yard fenced with barbed wire, the presence of fruit trees, and a chicken coop, the base of which was suspended approximately $20 \mathrm{~cm}$ above the ground, leaving a clearance in which the animal was observed.

L. (L.) amazonensis has been recorded in Bolivia, Brazil, Colombia, French Guyana and Paraguay. In Brazil, this parasite has been found in all regions, especially the Amazon Region. However, it is likely that the geographical distribution of $L$. (L.) amazonensis is broader than is currently known and that it also extends into other countries of South America where its sandfly vector is found (Lainson \& Shaw 1987, 2005, Grimaldi et al. 1989, MS/SVE 2010). This parasite is implicated as an etiological agent of CL (Lainson \& Shaw 1987, 2005). However, there are also human cases of VL, diffuse or anergic leishmaniasis and post-kala-azar dermal leishmaniasis attributed to this parasite (Barral et al. 1991, Aleixo et al. 2006) as well as canine VL (Tolezano et al. 2007, Hoffmann et al. 2012).

In the first year of study (2012), two autochthonous cases of CL were reported in the municipality of Corumbá. In the two following years (2013-2014), there were no reported cases of CL. Between January-July 2015, only one case of mucosal leishmaniasis was reported (MS 2015). However, due to lack of studies on aetiology and/or genotyping of Leishmania species in Corumbá, it is not possible infer that the aetiology of human cases of the disease.

As observed for Lu. longipalpis, it is possible that Lu. cruzi also has a permissive character and permits infection by other species of the genus Leishmania, which suggests that the adhesion mechanism of the parasite through lipophosphoglycans is not species specific or may occur by means of other mechanisms (Volf \& Myskova 2007). This has important implications for the transmission and evolution of the parasite, as it may contribute to the dispersal of Leishmania due to its ability to adapt to new vectors (Myskova et al. 2007), since the main vector of $L$. (L.) amazonensis, Bichromomyia flaviscutellata (Mangabeira, 1942), has not yet been found in the region (Galati et al. 1985, 1997, Santos et al. 1998, Almeida et al. 2010, Casaril et al. 2014, Oliveira 2015).

The incrimination and subsequent confirmation of a species as a vector of Leishmania should be based on several criteria, the first of which is the discovery of naturally infected wild females through the detection of the flagellate forms of the parasite on more than one occasion (Killick-Kendrick \& Ward 1981, Killick-Kendrick 1990). Another criterion is the isolation and typing of promastigotes from females that have not fed for more than 36 h (Ready 2013).
Due to its epidemiological complexity, cutaneous and $\mathrm{VL}$, the aetiology of which is attributed to $L$. (L.) amazonensis is characterised as a disease that is difficult to control and requires specific measures depending on the area of occurrence. Therefore, besides the establishment of early diagnosis and treatment, the proper identification of the species of Leishmania and the determination of its area of distribution are essential to the planning and adoption of prevention measures and the reduction of the exposure of the human population to the vector (Dorval et al. 2006, MS/SVE 2010).

Considering that $L$. (L.) infantum and $L$. (L.) amazonensis were identified in Corumbá and the lack of studies on aetiology of human and canine cases of leishmaniases, both visceral and cutaneous forms, in addition to clinical and epidemiological aspects, attention special should be given to the identification by genotyping of the parasites.

Experimental infection studies, undertaken by this research group, with both species, are currently underway and are necessary to gain a better understanding of the parasite-vector interaction. Studies for the identification of reservoir hosts should also be conducted, since some wild and domesticated mammals are considered to be hosts of different species of Leishmania (Ashford 2000).

In short, $L$. (L.) amazonensis DNA was detected for the first time in $L u$. cruzi collected in the urban area of Corumbá, an endemic area for VL and CL. The authors would like to emphasize the importance of this finding, since $L u$. cruzi, a suspected vector of $L$. (L.) infantum and adapted to the urban environment, could contribute to the dispersion and urbanisation of $L$. (L.) amazonensis. It is further relevant the fact that this species has been found associated with human and canine VL cases. Therefore, these findings point to the need for further investigation into the possible role of this sandfly as vector of this parasite.

\section{ACKNOWLEDGEMENTS}

To the Zoonosis Control Centre of Corumbá, for technical assistance and help during capture of sandflies.

\section{REFERENCES}

Aleixo JA, Nascimento ET, Monteiro GR, Fernandes MZ, Ramos AMO, Wilson ME, Pearson RD, Jeronimo SMB 2006. Atypical American visceral leishmaniasis caused by disseminated Leishmania amazonensis infection presenting with hepatitis and adenopathy. Trans R Soc Trop Med Hyg 100: 79-82.

Almeida PS, Nascimento JC, Ferreira AD, Minzão LD, Portes F, Miranda AM, Faccenda O, Andrade Filho JD 2010. Espécies de flebotomíneos (Diptera, Psychodidae) coletadas em ambiente urbano em municípios com transmissão de leishmaniose visceral do estado de Mato Grosso do Sul, Brasil. Rev Bras Entomol 54: 304-310.

Aransay AM, Scoulica E, Tselentis Y 2000. Detection and identification of Leishmania DNA within naturally infected sand flies by seminested PCR on minicircle kinetoplastic DNA. Appl Environ Microbiol 66: 1933-1938.

Ashford RW 2000. The leishmaniases as emerging and reemerging zoonoses. Int J Parasitol 30: 1269-1281.

Barral A, Pedral-Sampaio D, Grimaldi Jr G, Momen H, McMahon-Pratt D, de Jesus AR, Almeida R, Badaro R, Barral-Netto M, Carvalho EM, Johnson Jr WD 1991. Leishmaniasis in Bahia, Brazil: evidence that Leishmania amazonensis produces a wide spectrum of clinical disease. Am J Trop Med Hyg 44: 536-546. 
Casaril AE, Monaco NZN, Oliveira EF, Eguchi GU, Paranhos Filho AC, Pereira LE, Oshiro ET, Galati EAB, Mateus NLF, Oliveira AG 2014. Spatiotemporal analysis of sandfly fauna (Diptera: Psychodidae) in an endemic area of visceral leishmaniasis at Pantanal, central South America. Parasit Vectors 7: 364.

da Silva OS, Grunewald J 1999. Contribution to the sand fly fauna (Diptera: Phlebotominae) of Rio Grande do Sul, Brazil, and Leishmania (Viannia) infections. Mem Inst Oswaldo Cruz 94: 579-582.

Deane LM 1956. Leishmaniose visceral no Brasil. Estudos sobre reservatórios e transmissores realizados no estado do Ceará, Serviço Nacional de Educação Sanitária, Rio de Janeiro, 162 pp.

Dorval MEC, Oshiro ET, Cupollilo E, Camargo AC, Alves TP 2006. Ocorrência de leishmaniose tegumentar americana no estado do Mato Grosso do Sul associada à infecção por Leishmania (Leishmania) amazonensis. Rev Soc Bras Med Trop 39: 43-46.

El Tai NO, Osmar OF, El Fari M, Presber WH, Schönian G 2000. Genetic heterogeneity of ribosomal internal transcribed spacer in clinical samples of Leishmania donovani spotted on filter paper as revealed by single-strand conformation polymorphisms and sequencing. Trans R Soc Trop Med Hyg 94: 575-579.

Feliciangeli MD, Rodriguez N, Bravo A, Arias F, Guzman B 1994. Vectors of cutaneous leishmaniasis in north-central Venezuela. Med Vet Entomol 8: 317-324.

Freitas-Lidani KC, de Messias-Reason IJ, Ishikawa EAY 2014. A comparison of molecular markers to detect Lutzomyia longipalpis naturally infected with Leishmania (Leishmania) infantum. Mem Inst Oswaldo Cruz 109: 442-447.

Galati EAB 2014. Phlebotominae (Diptera, Psychodidae): classificação, morfologia, terminologia e identificação de adultos. Available from: fsp.usp.br/egalati/ApostilaPhlebotominae_2014_vol_I.pdf.

Galati EAB, Nunes VLB, Rego Jr FA, Oshiro ET, Rodrigues M 1997. Estudo de flebotomíneos (Diptera, Psychodidae) em foco de leishmaniose visceral no estado de Mato Grosso do Sul, Brasil. Rev Saude Publica 31: 378-390.

Galati EAB, Rego Jr FA, Nunes VLB, Oshiro ET 1985. Fauna flebotomínica do município de Corumbá, Mato Grosso do Sul, Brasil, e descrição de Lutzomyia forattinii, sp. n. (Diptera, Psychodidae, Phlebotominae). Rev Bras Entomol 29: 261-266.

Gontijo CMF, Melo MN 2004. Leishmaniose visceral no Brasil: quadro clínico, desafios e perspectivas. Rev Bras Epidemiol 7: 338-349.

Grimaldi GJ, Tesh RB, McMahon-Pratt DA 1989. Review of the geographic distribution and epidemiology of leishmaniasis in the New World. Am J Trop Med Hyg 41: 687-725.

Hoffmann AR, Navarro IT, Camargo Jr VE, Caldart ET, Breganó RM, Pereira PM 2012. Leishmania amazonensis in dog with clinical diagnosis of visceral leishmaniasis in Paraná state, Brazil - a case report. Semina 33 (Suppl. 2): 3265-3270.

Johnson PT, McConnell E, Hertig M 1963. Natural infections of leptomonad flagellates in Panamanian Phlebotomus sandflies. Exp Parasitol 14: 107-122.

Kamhawi S 2006. Phlebotomine sand flies and Leishmania parasites: friends or foes? Trends Parasitol 22: 439-445.

Katholi CR, Toe L, Merriweather A, Unnasch TR 1995. Determining the prevalence of Onchocerca volvulus infection in vector populations by polymerase chain reaction screening of pools of black flies. J Infect Dis 172: 1414-1417.

Killick-Kendrick R 1990. Phlebotomine vectors of the leishmaniasis: a review. Med Vet Entomol 4: 1-24.

Killick-Kendrick R, Ward RD 1981. Ecology of Leishmania. Parasitology 82: 143-152.
Lainson R, Rangel EF 2005. Lutzomyia longipalpis and the eco-epidemiology of American visceral leishmaniasis, with particular reference to Brazil - A Review. Mem Inst Oswaldo Cruz 100: 811-827.

Lainson R, Shaw JJ 1987. Evolution, classification and geographical distribution. In W Peters, R Killick-Kendrick (eds.), The leishmaniases in biology and medicine, Academic Press, London, p. 12-120.

Lainson R, Shaw JJ 2005. New world leishmaniasis. In FEG Cox, D Wakelin, SH Gillespie, DD Despommier (eds.), Topley \& Wilson's microbiology and microbial infections: parasitology, 10th ed., Hodder Arnold ASM Press, London, p. 313-349.

Lainson R, Shaw JJ, Ryan L, Ribeiro RSM, Silveira FT 1985. Leishmaniasis in Brazil. XXI. Visceral leishmaniasis in the Amazon Region and further observations on the role of Lutzomyia longipalpis (Lutz \& Neiva, 1912) as the vector. Trans R Soc Trop Med Hyg 79: 223-226.

Lainson R, Shaw JJ, Silveira FT, de Souza AAA, Braga RR, Ishikawa EAY 1994. The dermal leishmaniases of Brazil, with special reference to the ecoepidemiology of the disease in Amazonia. Mem Inst Oswaldo Cruz 89: 435-443.

Martín-Sánchez J, Gállego M, Barón S, Castillejo S, Morillas-Marquez F 2006. Pool screen PCR for estimating the prevalence of Leishmania infantum infection in sandflies (Diptera: Nematocera, Phlebotomidae). Trans R Soc Trop Med Hyg 100: 527-532.

Michalsky EM, Fortes-Dias CL, Pimenta PF, Secundino NF, Dias ES 2002. Assessment of PCR in the detection of Leishmania spp in experimentally infected individual phlebotomine sandflies (Diptera: Psychodidae: Phlebotominae). Rev Inst Med Trop Sao Paulo 44: 255-259.

MS - Ministério da Saúde Brasil 2015. Sistema de Informação de Agravos de Notificação. Available from: dtr2004.saude.gov.br/sinanweb.

MS/SVE - Ministério da Saúde/Superintendência de Vigilância Epidemiológica Brasil 2010. Manual de vigilância da leishmaniose tegumentar americana, MS, Brasília, $180 \mathrm{pp}$.

Myskova J, Svobodova M, Beverley SM, Volf P 2007. A lipophosphoglycan-independent development of Leishmania in permissive sand flies. Microbes Infect 9: 317-324.

Oliveira EF 2015. Vectorial capacity of Lutzomyia (Lutzomyia) cruzi (Diptera: Psychodidae) for Leishmania (Leishmania) infantum, PhD Thesis, Universidade de São Paulo/Faculdade de Saúde Pública, São Paulo, 203 pp.

Paiva BR, Oliveira AG, Dorval MEMC, Galati EAB, Malafronte RS 2010. Species-specific identification of Leishmania in naturally infected sand flies captured in Mato Grosso do Sul state, Brazil. Acta Trop 115: 126-130.

Paiva BR, Secundino NFC, Nascimento JC, Pimenta PFP, Galati EAB, Andrade-Júnior HF, Malafronte RS 2006. Detection and identification of Leishmania species in field-captured phlebotomine sandflies based on mini-exon gene PCR. Acta Trop 99: 252-259.

Paiva BR, Secundino NFC, Pimenta PFP, Galati EAB, Andrade-Júnior HF, Malafronte RS 2007. Padronização de condições para detecção de DNA de Leishmania spp em flebotomíneos (Diptera, Psychodidae) pela reação em cadeia da polimerase. Cad Saude Publica 23: 87-94.

Perez JE, Ogusuku E, Inga R, Lopez M, Monje J, Paz L, Nieto E, Arevalo J, Guerra H 1994. Natural Leishmania infection of Lutzomyia spp in Peru. Trans R Soc Trop Med Hyg 88: 161-164.

Perruolo G, Rodríguez NN, Feliciangeli MD 2006. Isolation of Leishmania (Viannia) braziliensis from Lutzomyia spinicrassa (species group Verrucarum) Morales Osorno Mesa, Osorno and Hoyos 1969, in the Venezuelan Andean Region. Parasite 13: 17-22.

Pita-Pereira D, Alves CR, Souza MB, Brazil RP, Bertho AL, de Figueiredo BA, Britto CC 2005. Identification of naturally in- 
fected Lutzomyia intermedia and Lutzomyia migonei with Leishmania (Viannia) braziliensis in Rio de Janeiro (Brazil) revealed by a PCR multiplex non-isotopic hybridisation assay. Trans $R$ Soc Trop Med Hyg 99: 905-913.

Pita-Pereira D, Cardoso MAB, Alves CR, Brazil RP, Britto C 2008. Detection of natural infection in Lutzomyia cruzi and Lutzomyia forattinii (Diptera: Psychodidae: Phlebotominae) by Leishmania infantum chagasi in an endemic area of visceral leishmaniasis in Brazil using a PCR multiplex assay. Acta Trop 107: 66-69.

Ready PD 2013. Biology of phlebotomine sand flies as vectors of disease agents. Аnnu Rev Entomol 58: 227-250.

Santos SO, Arias J, Hoffmann MP, Furlan MBG, Ferreira WF, Pereira C, Ferreira L 2003. The presence of Lutzomyia longipalpis in a focus of American visceral leishmaniasis where the only proven vector is Lutzomyia cruzi, Corumbá, Mato Grosso do Sul state. Rev Soc Bras Med Trop 36: 633-634.

Santos SO, Arias J, Ribeiro AA, Hoffmann MP, Freitas RA, Malacco MAF 1998. Incrimination of Lutzomyia cruzi as a vector of American visceral leishmaniasis. Med Vet Entomol 12: 315-317.

Savani ES, Nunes VL, Galati EAB, Castilho TM, Zampieri RA, Floeter-Winter LM 2009. The finding of Lutzomyia almerioi and Lutzomyia longipalpis naturally infected by Leishmania spp in a cutaneous and canine leishmaniasis focus in Serra da Bodoquena, Brazil. Vet Parasitology 160: 18-24.
Schönian G, Nascreddin A, Dinse N, Schweynoch C, Schallig HD, Presber W, Jaffe CL 2003. PCR diagnosis and characterization of Leishmania in local and imported clinical samples. Diagn Microbiol Infect Dis 47: 349-358.

Sherlock IA 1996. Ecological interactions of visceral leishmaniasis in the state of Bahia, Brazil. Mem Inst Oswaldo Cruz 91: 671-683.

Smyth AJ, Ghosh A, Hassan MQ, Basu D, De Bruijn MH, Adhya S, Mallik KK, Barker DC 1992. Rapid and sensitive detection of Leishmania kinetoplast DNA from spleen and blood samples of kala-azar patients. Parasitology 105: 183-192.

Tauil PL 2006. Perspectivas de controle de doenças transmitidas por vetores no Brasil. Rev Soc Bras Med Trop 39: 275-277.

Tolezano JE, Uliana SRB, Taniguchi HH, Araújo MFL, Barbosa JAR, Barbosa JER, Floeter-Winter LM, Shaw JJ 2007. The first records of Leishmania (Leishmania) amazonensis in dogs (Canis familiaris) diagnosed clinically as having canine visceral leishmaniasis from Araçatuba county, São Paulo state, Brazil. Vet Parasitol 149: $280-284$

Volf P, Myskova J 2007. Sand flies and Leishmania: specific versus permissive vectors. Trends Parasitol 23: 91-92.

Young DG, Duncan MA 1994. Guide to the identification and geographic distribution of Lutzomyia sand flies in Mexico, the West Indies, Central and South America (Diptera: Psychodidae), Associated Publishers/American Entomological Institute, Gainesville, 887 pp. 